\title{
Evaluation of Boldine Activity against Intracellular Amastigotes of Leishmania amazonensis
}

\author{
Isabel Cristina Salama', Cristina Arrais-Lima', Wagner Welber Arrais-Silva ${ }^{1,2, *}$ \\ 'Laboratório de Parasitos e Vetores (LAPAV), Instituto de Ciências Biológicas e da Saúde, Campus Universitário do Araguaia, Universidade Federal \\ de Mato Grosso, Avenida Valdon Varjão, 6390 - Barra do Garças, Mato Grosso, CEP 78600-000, Brazil; ²Departamento de Morfologia, Centro de \\ Ciências Biológicas e da Saúde, Universidade Federal de Sergipe, Avenida Marechal Rondon, S/N - Jardim Rosa Elze - São Cristóvão, SE, CEP \\ 49100-000, Brazil
}

\begin{abstract}
Leishmaniasis is a neglected and endemic disease that affects poorest population mainly in developing countries. A lack of adequate and definitive chemotherapeutic agents to fight against this infection has led to the investigation of numerous compounds. The aim of this study was to investigate in vitro activity of boldine against Leishmania amazonensis murine cell infection. Boldine ((S)-2,9-dihydroxy-1,10-dimethoxy-aporphine) is an aporphine alkaloid found abundantly in the leaves/bark of boldo (Peumus boldus Molina), a widely distributed tree native to Chile. The in vitro system consisted of murine macrophage infection with amastigotes of $L$. amazonensis treated with different concentrations from 50 to $600 \mu \mathrm{g} / \mathrm{ml}$ of boldine for $24 \mathrm{hr}$. Intracellular parasite destruction was assessed by morphological examination and boldine cytotoxicity to macrophages was tested by the MTT viability assay. When cells were treated with $100 \mu \mathrm{g} / \mathrm{ml}$ of boldine the reduction of parasite infection was $81 \%$ compared with untreated cultures cells. Interestingly, boldine-treatment caused a concentration-dependent decrease of macrophage infection that culminated with $96 \%$ of reduction when cells were submitted to $600 \mu \mathrm{g} / \mathrm{ml}$ of boldine. Cell cultures exposed to $100 \mu \mathrm{g} / \mathrm{ml}$ of boldine and $300 \mu \mathrm{g} / \mathrm{ml}$ of Glucantime ${ }^{\circledR}$ during $24 \mathrm{hr}$ showed a significant reduction of $50 \%$ in parasitized cells compared with cell cultures exposed just to Glucantime ${ }^{\circledR}$. The study showed that treatment with boldine produces a better effect than treatment with the reference antimonial drug, glucantime, in L. amazonensis infected macrophage. Our results suggest that boldine is a potentially useful agent for the treatment of leishmaniasis.
\end{abstract}

Key words: Leishmania amazonensis, anti-parasitic activity, boldo, neglected disease

Leishmaniasis is an endemic zoonosis caused by several species of the genus Leishmania, a cell obligate parasite, transmitted through the bite of an infected sandfly that can cause a range of symptoms from cutaneous to visceral lesions in humans [1]. Approximately 0.2-0.4 million cases of visceral leishmaniasis, and about 0.7-1.2 million of cases of cutaneous leishmaniasis are registered annually, demonstrating the importance of this disease [2].

The control strategy is based on sinantropic vectors combat, effective diagnosis, and chemotherapy. In fact, the development of new and cost-effective alternative therapeutic strategies for leishmaniasis has become a high priority [3], mainly due to their high toxicity and lack of efficacy in some cases of leishmaniasis [4-6].

\footnotetext{
- Received 30 November 2016, revised 2 March 2017, accepted 10 March 2017

*Corresponding author (warrais@ufs.br)

(C) 2017, Korean Society for Parasitology and Tropical Medicine

This is an Open Access article distributed under the terms of the Creative Commons

Attribution Non-Commercial License (http://creativecommons.org/licenses/by-nc/4.0)

which permits unrestricted non-commercial use, distribution, and reproduction in any

medium, provided the original work is properly cited.
}

In recent years, considerable attention has been given to studying plants in an attempt to search for new antileishmanial drugs [7]. Identification of natural products and the wide variety of separation techniques available could increase the probability of finding novel products that in turn could lead to the development of new pharmaceutical compounds [8]. However, novel therapeutics for diseases endemic to the third world would seem out of reach. The costs associated with creating, maintaining, and screening large compound libraries are high. Thus, the development of drugs for leishmaniasis is hampered by the general lack of interest by the pharmaceutical industry in this class of disease; less than $1 \%$ of all new drugs target neglected tropical diseases [9].

Therefore, a strategy based on the testing of drugs already in human use and originally designed and evaluated for nonrelated diseases can be another alternative [6]. Recently, tamoxifen, an antineoplastic agent for the prophylactic treatment of malignancies was tested against cutaneous leishmaniasis with promising results $[10,11]$.

Boldine [(S)-2,9-dihydroxy-1,10-dimethoxy-aporphine] is 
an aporphine alkaloid found abundantly in the leaves/bark of boldo (Peumus boldus Molina), a widely distributed tree native to Chile [12]. Boldine has been reported to have several pharmacological activities, such as anti-inflammatory, antipyretic, antidiabetic, antiatherogenic, antiplatelet, antitumor promoting and cytoprotective effects [13]. Recently, a study showed that boldine increased NO bioavailability into endothelial cells and restored endothelial functions [14]. It has been well established that NO-dependent mechanisms are critical for control of Leishmania infection [15]. Thus, based on Boldine proprieties and aiming to identify a new antileishmanial agent, the present work was carried out to investigate the effect of boldine using in vitro leishmaniasis model.

Primary mouse macrophages were obtained from normal BALB/c mice by peritoneal lavage $[16,17]$. Leishmania amazonensis (MHOM/BR/73/M2269) amastigote forms were isolated from active skin lesions of BALB/c mice as described previously [16]. The parasites were suspended in RPMI 1640 medium and used immediately after isolation. Peritoneal macrophages were infected with L. amazonensis amastigotes (3:1 parasites/host cell) for $1 \mathrm{hr}$, as previously described [18]. After the interaction period, the cultures were washed to remove extracellular parasites, and fresh medium was added to the cell culture supplemented with 50 to $600 \mu \mathrm{g} / \mathrm{ml}$ of boldine or $300 \mu \mathrm{g} / \mathrm{ml}$ of Glucantime ${ }^{\circledR}$ (Sanofi-Aventis, Brazil), and incubated at $35^{\circ} \mathrm{C}, 5 \%$ of $\mathrm{CO}_{2}$ for $24 \mathrm{hr}$, as previously described [19]. Intracellular parasite destruction was assessed by morphological examinations. Briefly, for evaluating the percentage of infected macrophages and the number of amastigotes per macrophage, cells on coverslips were stained with Giemsa [17]. Intracellular amastigotes which were exclusively localized in parasitophorous vacuoles [20] were examined microscopically at a magnification of $1,000 \times$. About 600 cells were counted per triplicate coverslip [21].

Boldine (Sigma-Aldrich, St. Louis, Missouri, USA) cytotoxicity to macrophages was tested by the MTT viability assay. Briefly, after incubation of peritoneal derived macrophages with 50 to $600 \mathrm{\mu g} / \mathrm{ml}$ of boldine for $24 \mathrm{hr}$, cells were also incubated with the highest concentration of DMSO used for boldine solubilization $(0.01 \%)$. The formation of formazan was measured by adding 3-(4,5-dimethylthiazol-2-yl)-2,5-diphenyltetrazolium bromide (MTT; Molecular Probes, Eugene, Oregon, USA) $0.5 \mathrm{mg} / \mathrm{ml}$ and incubation of the cultures at $37^{\circ} \mathrm{C}$ in the dark. After $4 \mathrm{hr}$, the medium was removed, $200 \mu \mathrm{l}$ of DMSO was added per well, and the absorbance was measured using an ELISA reader at $540 \mathrm{~nm}$ (Labsystems Multiskan, Helsinki,
Finland). All experiments were repeated at least 3 times, and the results are expressed as the mean $\pm S D$. Data obtained under different conditions were analyzed statistically by the Student's t-test, with levels of significance set at $P \leq 0.05$.

Peritoneal macrophages were efficiently infected with $L$. amazonensis for $24 \mathrm{hr}$, showing a significantly high number of infected macrophages, $72 \%$. Similar results were found with DMSO treated macrophages (Fig. 1A). In cell cultures subjected to $50 \mu \mathrm{g} / \mathrm{ml}$ of boldine for $24 \mathrm{hr}$, there was a significant reduction of $50 \%$ of the infected macrophages. When cells were treated with $100 \mu \mathrm{g} / \mathrm{ml}$ of boldine, the reduction was $81 \%$ compared with untreated cultures cells. Interestingly, boldine-treatment caused a concentration-dependent decrease of macrophage infection that culminated with $96 \%$ of reduction when cells were submitted to $600 \mu \mathrm{g} / \mathrm{ml}$ of boldine. This performance was 4-fold higher than cells treated with $300 \mu \mathrm{g} / \mathrm{ml}$ of Glucantime ${ }^{\circledR}$, the first choice drug to treat leishmaniasis (Fig. 1A).

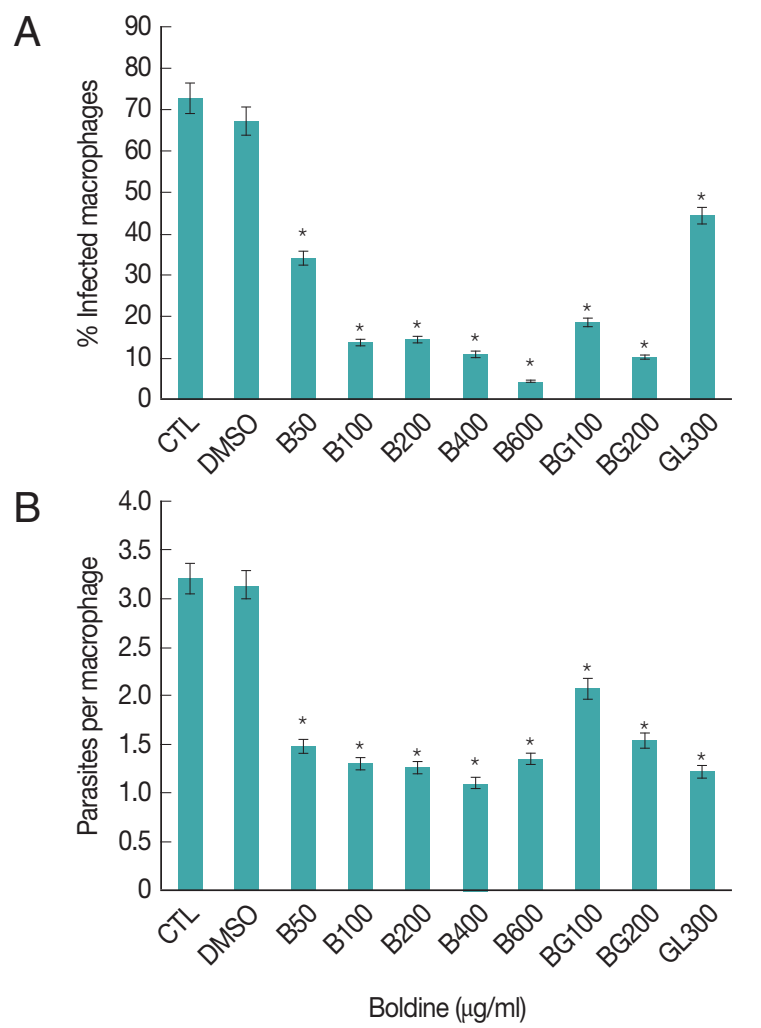

Fig. 1. Effects of boldine on L. amazonensis infected macrophages. Peritoneal macrophages were infected with $L$. amazonensis amastigotes and cultured at $37^{\circ} \mathrm{C}$ and $5 \%$ of $\mathrm{CO}_{2}$ for 24 $\mathrm{hr}$. The percentage of infected macrophages $(A)$ and the nnumber of amastigotes per macrophage (B) were determined as described in Materials and Methods. The result represents the mean \pm SD of 3 experiments. The significance of the difference between cells cultures treatments is indicated: ${ }^{*} P \leq 0.05$. 
We addressed the question of whether the combination of Boldine-Glucantime ${ }^{\circledR}$ treatment reduces the number of infected murine peritoneal macrophages. Cell cultures exposed to 100 $\mu \mathrm{g} / \mathrm{ml}$ of boldine and $300 \mu \mathrm{g} / \mathrm{ml}$ of Glucantime ${ }^{\circledR}$ during $24 \mathrm{hr}$ showed a significant reduction of 50\% in parasitized cells compared with cell cultures exposed just to Glucantime ${ }^{\circledR}$ (Fig. 1A). These data indicated that boldine treatment increases the resistance of macrophages to L. amazonensis infection and corroborates with Glucantime ${ }^{\circledR}$ to reduce the number of infected cells.

We also analyzed the parasite per cell, as part of parasite burden investigation. As shown in Fig. 1B, boldine treatment induced a significant reduction in the number of parasites inside the cells (decrease of 50\%) at initial experimental concentration $(50 \mu \mathrm{g} / \mathrm{ml})$. Interestingly, the reduction in parasite per cell observed in macrophages under lower concentration was observed in cells cultured with higher concentration of boldine $(600 \mu \mathrm{g} / \mathrm{ml})$. However, these data were similar to the Glucantime ${ }^{\circledR}$ treated cell (Fig. 1B).

Viability was determined in cells treated with boldine and/ or Glucantime ${ }^{\circledR ;}$; there was no significant difference in the OD values obtained by the MTT assay in infected peritoneal macrophages submitted to all experimental concentration of boldine. In addition, higher concentration of boldine $(600 \mu \mathrm{g} /$ $\mathrm{ml}$ ) showed significantly high OD values by the MTT assay than Glucantime ${ }^{\circledR}$ treated cells (Fig. 2). The results also indicated no toxicity of boldine treatment in non-infected murine macrophage.

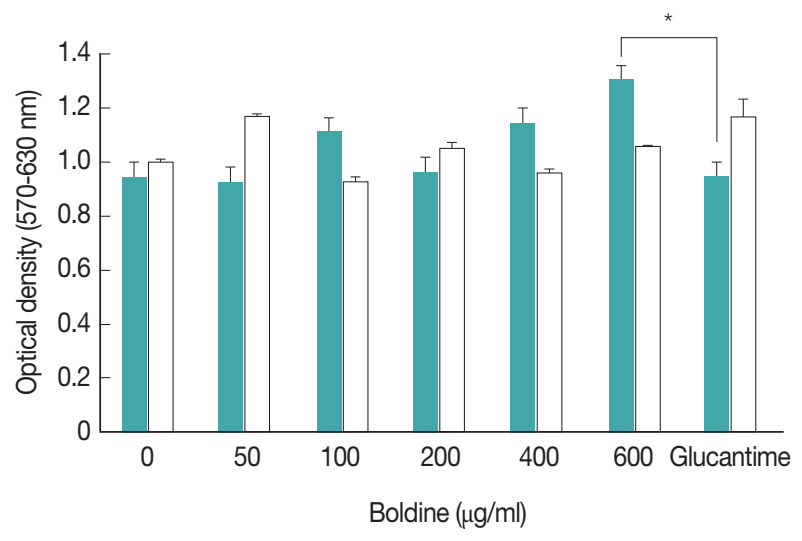

Fig. 2. Effects of boldine on peripheral macrophages. The MTT production by macrophages was determined in cell cultures treated with several concentrations of boldine in infected murine macrophage ( $\square$ ) or in non-infected murine macrophage as control $(\square)$. Results represent the mean \pm SD of 1 representative experiment out of 3 independently performed experiments with similar results. The significance of the difference between cells cultures treatments is indicated: ${ }^{*} P \leq 0.05$.
Boldine, an aporphine alkaloid found in the leaves/bark of boldo (P. boldus), a widely distributed tree native to Chile has been shown to have potential novel activities against viruses [22] and cytotoxic and chemotherapeutic properties in breast cancer [23]. Hung et al. [24] studied, for the first time, the leishmanicidal properties of the boldine in the promastigotes of Leishmania mexicana. Mollatagui et al. [25] also reported boldine activity against $\mathrm{L}$. donovani infected macrophages. However, there are no reports available regarding the activity of Boldine against New World Leishmania species.

This research was designed to study the in vitro activity of boldine on peritoneal murine macrophages infected with $L$. amazonensis amastigotes. Treatment was initiated $1 \mathrm{hr}$ after infection, an interval of time that allowed for the establishment of the amastigotes phagocytosis, and ensured a homogeneous cell culture infection. Results revealed marked improvement of macrophage capacity in decrease of the parasite burden. Similarly, boldine treatment showed significant reductions of the parasite cell burden and trypanocidal and anti-viral activity using in vitro model $[22,26]$. The biological relevance of boldine treatment appears to be correlated with its immunological modulatory effect by oxidative stress modulation [27].

Boldine is extensively prescribed as a potent "natural" antioxidant and possesses several health-promoting properties like antiinflammatory, antitumor promoting, antidiabetic, and cytoprotective. It is a relatively safe drug judging from the many animal studies and its widespread use as over-the-counter drug supplement. A relatively high boldine concentration is needed to induce lethality in laboratory animal tests. Kreitmair [28] demonstrated that an oral administration of 500-1,000 mg/kg of boldine was required to cause death in mice and guinea pigs, respectively. In the present study, boldine was evaluated for its cytotoxic effect in macrophage cells using the MTT cell viability assay. The macrophages, whether infected or not with Leishmania, and treated with boldine showed similar viability to non-treated cells even when treated with high boldine concentration.

In conclusion, this study proved, for the first time, boldine's in vitro protective activity against $L$. amazonensis macrophage infection, thus, setting the stage for boldine as a suitable lead compound for the synthesis of more effective and less toxic antileishmanial derivatives.

\section{ACKNOWLEDGMENT}

This work was supported by Fundação de Amparo a Pesqui- 
sa do Estado de Mato Grosso under grant no. 161229/2014.

\section{CONFLICT OF INTEREST}

We have no conflict of interest related to this work.

\section{REFERENCES}

1. Grimaldi G Jr, Tesh RB. Leishmaniasis of the New World: current concepts and implications for future research. Clin Microbiol Rev 1993; 6: 230-250.

2. Alvar J, Vélez ID, Bern C, Herrero M, Desjeux P, Cano J, Jannin J, den Boer M; WHO Leishmaniasis Control Team. Leishmaniasis worldwide and global estimates of its incidence. PLoS One 2012; 7: e35671.

3. Frézard F, Demicheli C, Ribeiro RR. Pentavalent antimonials: new perspectives for old drugs. Molecules 2009; 14: 2317-2336.

4. Sundar S, Jha TK, Thakur CP, Engel J, Sindermann H, Fischer C, Junge $\mathrm{K}$, Bryceson A, Berman J. Oral miltefosine for Indian visceral leishmaniasis. N Engl J Med 2002; 347: 1739-1746.

5. Kedzierski L, Curtis JM, Kedzierska K. Early CD44hiCD ${ }^{4+}$ and $\mathrm{CD}_{4} 4 \mathrm{hiCD}^{8+} \mathrm{T}$ cell numbers and the absence of mannose-rich glycoconjugates determine the protective outcome of anti-leishmanial immunity. Parasitology 2009; 136: 833-840.

6. Murray HW. Progress in the treatment of a neglected infectious disease: visceral leishmaniasis. Expert Rev Anti Infect Ther 2004; 2: 279-292.

7. Brito AM, Dos Santos D, Rodrigues SA, Brito RG, Xavier-Filho L. Plants with anti-Leishmania activity: Integrative review from 2000 to 2011. Pharmacogn Rev 2013; 7: 34-41.

8. Saklani A, Kutty SK. Plant-derived compounds in clinical trials. Drug Discov Today 2008; 13: 161-171.

9. Trouiller P, Olliaro P, Torreele E, Orbinski J, Laing R, Ford N. Drug development for neglected diseases: a deficient market and a public health policy failure. Lancet 2002; 359: 2188-2194.

10. Eissa MM, Amer EI, El Sawy SM. Leishmania major: activity of tamoxifen against experimental cutaneous leishmaniasis. Exp Parasitol 2011; 128: 382-390.

11. Trinconi CT, Reimão JQ, Yokoyama-Yasunaka JK, Miguel DC, Uliana SR. Combination therapy with tamoxifen and amphotericin B in experimental cutaneous leishmaniasis. Antimicrob Agents Chemother 2014; 58: 2608-2613.

12. Mukhtar MR1, Aziz AN, Thomas NF, Hadi AH, Litaudon M, Awang K. Grandine A, a new proaporphine alkaloid from the bark of Phoebe grandis. Molecules 2009; 23: 1227-1233.

13. O'Brien P, Carrasco-Pozo C, Speisky H. Boldine and its antioxidant or health-promoting properties. Chem Biol Interact 2006; 159: 1-17.

14. Lau YS, Tian XY, Huang Y, Murugan D, Achike FI, Mustafa MR. Boldine protects endothelial function in hyperglycemia-induced oxidative stress through an antioxidant mechanism. Biochem
Pharmacol 2013; 85: 367-375.

15. Liew FY, Li Y, Millott S. Tumour necrosis factor (TNF-alpha) in leishmaniasis. II. TNF-alpha-induced macrophage leishmanicidal activity is mediated by nitric oxide from L-arginine. Immunology 1990; 71: 556-559.

16. Barbieri CL, Giorgio S, Merjan AJ, Figueiredo EN. Glycosphingolipid antigens of Leishmania (Leishmania) amazonensis amastigotes identified by use of a monoclonal antibody. Infect Immun 1993; 61: 2131-2137.

17. Giorgio S, Linares E, Ischiropoulos H, Von Zuben FJ, Yamada A, Augusto O. In vivo formation of electron paramagnetic resonance-detectable nitric oxide and nitrotyrosine is not impaired during murine leishmaniasis. Infect Immun 1998; 66: 807-814.

18. Colhone MC, Arrais-Silva WW, Picoli C, Giorgio S. Effect of hypoxia on macrophage infection by Leishmania amazonensis. J Parasitol 2004; 90: 510-515.

19. Degrossoli A, Giorgio S. Functional alterations in macrophages after hypoxia selection. Exp Biol Med 2007; 232: 88-95.

20. Chang KP. Human cutaneous leishmania in a mouse macrophage line: propagation and isolation of intracellular parasites. Science 1980; 209: 1240-1242.

21. Linares, E, Augusto O, Barão SC, Giorgio S. Leishmania amazonensis infection does not inhibit systemic nitric oxide levels elicited by lipopolysaccharide in vivo. J Parasitol 2000; 86: 78-82.

22. Tietjen I, Ntie-Kang F, Mwimanzi P, Onguéné PA, Scull MA, Idowu TO, Ogundaini AO, Meva'a LM, Abegaz BM, Rice CM, Andrae-Marobela K, Brockman MA, Brumme ZL, Fedida D. Screening of the Pan-African Natural Product library identifies ixoratannin A-2 and boldine as novel HIV-1 inhibitors. PLoS One 2015; 10: e0121099.

23. Paydar M, Kamalidehghan B, Wong YL, Wong WF, Looi CY, Mustafa MR. Evaluation of cytotoxic and chemotherapeutic properties of boldine in breast cancer using in vitro and in vivo models. Drug Des Devel Ther 2014; 8: 719-733.

24. Hung J, Castillo J, Jiménez G, Hasegawa M, Rodriguez M. Spectroscopic study of antileishmanial drug incubated in the promastigotes of Leishmania mexicana. Spectrochim Acta A Mol Biomol Spectrosc 2003; 59: 3177-3183.

25. Mollataghi A, Coudiere E, Hadi AHA, Mukhtar MR, Awang K, Litaudon M, Ata A. Anti-acetylcholinesterase, anti- $\alpha$-glucosidase, anti-leishmanial and anti-fungal activities of chemical constituents of Beilschmiedia species. Fitoterapia 2012; 83: 298-302.

26. Morello A, Lipchenca I, Cassels Bk, Speisky H, Aldunate J, Repetto Y. Trypanocidal effect of boldine and related alkaloids upon several strains of Trypanosoma cruzi. Comp Biochem Physiol Pharmacol Toxicol Endocrinol 1994; 107: 367-371.

27. Moreira RRD, Carlos IZ, Vilegas W. Release of Intermediate Reactive Hydrogen Peroxide by Macrophage Cells Activated by Natural Products. Biol Pharm Bull 2001; 24: 201-204.

28. Kreitmair H. Pharmacological effects of the alkaloid of Peumus boldus molina. Pharmazie 1952; 7: 507-511. 